\title{
FACILITY FOR HYDROGENATION AND THERMAL TESTING OF INTERNALLY PRESSURIZED DUMMY FUEL RODS
}

\author{
V.A. Dolgiy, V.A. Chunosov, D.L. Kokosha, T.P. Chernyayeva, V.M. Grytsyna, G.P. Riedkina \\ "Nuclear Fuel Cycle" Science and Technology Establishment \\ National Science Center "Kharkov Institute of Physics and Technology”, Kharkiv, Ukraine \\ E-mail: gordaya@kipt.kharkov.ua
}

A facility allowing to conduct experiments on dummy fuel rods up to $250 \mathrm{~mm}$ long, at temperatures up to $700{ }^{\circ} \mathrm{C}$ is presented. The designed facility is unique in that the conditions for the tests to be conducted on it most closely resemble (except for irradiation) those of fuel rods operation, loading and storage in SFDSF. All test parameters are programmed and regulated by special sensors, which brings the experiment on fuel rod temperature effect and pressure under the cladding as close as possible to the conditions of fuel rod operation in reactor and further storage in SFDSF. Hydride Reorientation Test (HRT) was conducted on dummy fuel rod sunder internal pressure of $3 . .5 \mathrm{MPa}$ (at room temperature) and with hydrogen concentration of $50 \ldots 300 \mathrm{ppm}$ in the modes that simulate SNF handling with limiting heating to $410^{\circ} \mathrm{C}$ and accidents with seven $410 \leftrightarrow 300$ and $410 \leftrightarrow 180{ }^{\circ} \mathrm{C}$ thermal cycles. It has been demonstrated that the effectiveness of the influence of the test conditions in the specified modes on hydride reorientation increases with increasing hydrogen concentration and tangential stresses in the dummy fuel rod claddings. It has been shown that the test samples design, control and measurement devices, as well as the parameters estimated during the test and further investigations fully meet the test requirements.

\section{INTRODUCTION}

It is essential to develop understanding of the processes occurring in fuel rods with $\mathrm{Zr}-1 \% \mathrm{Nb}$ claddings with different internal pressures under cladding for substantiation of FA and SFA safety in all WWER-1000 and WWER-440 reactors at all stages of their operation and during SFA handling in SFDSF. For testing dummy fuel rods in the conditions that are as close as possible to those of FA operation, SFA loading and storage in SFDSF, a facility for hydrogenation and thermal testing of internally pressurized dummy fuel rods was created at NFC STE NSC KIPT.

\section{FACILITY FOR HYDROGENATION AND THERMAL CYCLING (FHTC)}

FHTC is a facility for hydrogenation and thermal testing of dummy fuel rods under internal pressure under the cladding. In the course of all tests conducted using the FHTC, measurements, control and adjustment of such parameters as temperature, internal and external dummy fuel rod pressure, vacuum or pressure of the medium (argon, helium, hydrogen) in the heating furnace are carried out. A diagram and appearance of this facility is given below.

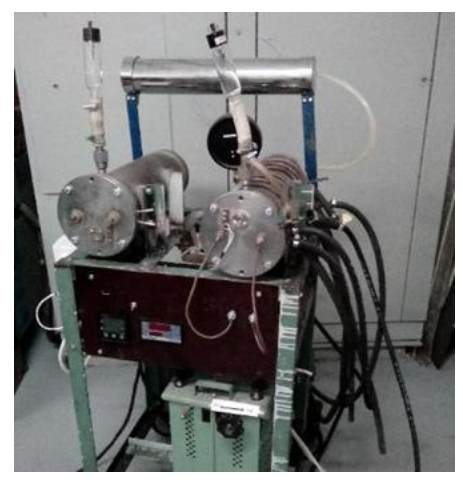

Fig. 1. Facility Appearance
The facility allows working with dummy fuel rods up to $250 \mathrm{~mm}$ in length, at temperatures up to $450{ }^{\circ} \mathrm{C}$. The vacuum in the chamber is $1.322 \cdot 10^{-4} \mathrm{~Pa}$. The mode is controlled by the Lab View computer program allowing to preset the required heating rate and ensures the required temperature is maintained during the test with an accuracy of $0.2^{\circ} \mathrm{C}$ (Figs. 1 and 2).

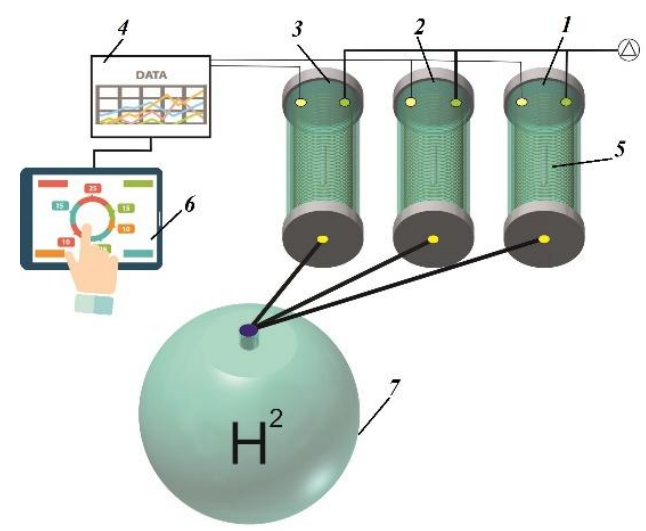

Fig. 2. Facility Diagram:

1 - chamber 1; 2 - chamber $2 ; 3$ - chamber 3; 4 - measurement control; 5 -sample;

6 - control panel; 7 - hydrogen

The facility was developed for investigation of the processes occurring in fuel rods during FA operation and SFA storage.

The facility includes the following units:

- vacuum pumping unit;

- gas feeding system;

- power supply system;

- diagnostic system;

- temperature sensors;

- pressure sensors;

- geometry control sensors;

- three experimental chambers. 
Facility Specifications

\begin{tabular}{|l|c|}
\hline Characteristics & Value \\
\hline 1. Supply voltage & $380 \mathrm{~V}$ \\
\hline $\begin{array}{l}\text { 2. Furnace No 1 and 2 } \\
\text { capacity }\end{array}$ & $3 \mathrm{~kW}$ \\
\hline 3. Furnace No 2 capacity & $1 \mathrm{~kW}$ \\
\hline $\begin{array}{l}\text { 4. Chamber pressure, furnace } \\
\text { No 1 }\end{array}$ & $50 \mathrm{~atm}$ \\
\hline $\begin{array}{l}\text { 5. Chamber pressure, } \\
\text { chamber furnace No 1 and 2 }\end{array}$ & $0.1 \mathrm{~atm}$ \\
\hline $\begin{array}{l}\text { 6. Internal pressure under } \\
\text { sample cladding }\end{array}$ & Up to $150 \mathrm{~atm}$ \\
\hline 7. Vacuum & $1.3 \cdot 10^{-4} \mathrm{~mm} \mathrm{Hg}$ \\
\hline $\begin{array}{l}\text { 8. Gas environment in the } \\
\text { chamber }\end{array}$ & $\begin{array}{c}\text { helium, nitrogen } \\
\text { and others }\end{array}$ \\
\hline 9. Furnace temperatures & Up to $700{ }^{\circ} \mathrm{C}$ \\
\hline 10. Trap & liquid nitrogen \\
\hline $\begin{array}{l}\text { 11. Amount of hydrogen in } \\
\text { the cladding }\end{array}$ & Up to $450 \mathrm{ppm}$ \\
\hline
\end{tabular}

The facility is comprised of three chambers each fitted with sensors and connected to the control system. The temperature control unit allows creating sixteen temperature intervals in each furnace, which is very convenient for simulation of accident conditions in SFDSF. The facility is capable of maintaining preset gas pressure under cladding and monitoring gas pressure changes throughout the entire test cycle.

Chamber No 1 has a steel cooled body and a revolving furnace with a maximum temperature up to $700{ }^{\circ} \mathrm{C}$. It allows thermal cycling and annealing of samples both in vacuum and at a pressure of up to $50 \mathrm{MPa}$.

Chamber No 2 has a quartz body with an external heater, which allows to prevent possible influence of the heater and chamber material on the results of the experiment. The chamber allows to conduct samples hydrogenation, annealing and thermal cycling both in vacuum and at atmospheric pressure, in a preset gas environment, with controlled gas pressure under dummy fuel rod cladding during the experiment. All these processes can be performed on a single dummy fuel rod without chamber reloading.

Chamber No 3 has a quartz body and a furnace in the chamber and allows carrying out, in vacuum or at atmospheric pressure, in a preset gas environment, thermal cycling or annealing of several samples with pressure control inside each sample during the experiment.

This scheme makes it possible to compare samples with different characteristics under similar processing conditions.

The facility is capable of measuring geometry changes during testing, which expands the scope of testing significantly.

The facility is unique in that testing to study the processes occurring in fuel rods during FA operation and SFA storage completely simulate the processes occurring in fuel rods (changes in the fuel rod pressure, temperature and cladding hydrogenation). All processes take place without stopping the facility, which brings the experiment on the effect of fuel rod temperature, medium and stresses in dummy fuel rod cladding as close as possible to reactor conditions. The developed facility for hydrogenation and thermal testing of the dummy fuel rods under internal pressure under the cladding allows creating both compressive and tensile stresses. The facility has a considerably reduced length of the hydrogen feeding system and uses the materials with low hydrogen absorption capacity, which significantly increases the reproducibility of the results during hydrogenation of the samples.

Fig. 3 shows the appearance of the test dummy fuel rod.

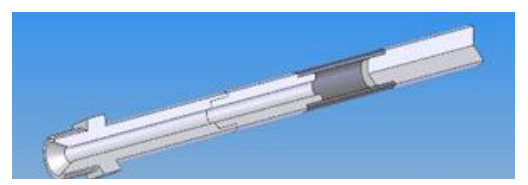

Fig. 3.Appearance of the test dummy fuel rod

To check performance of the facility, dummy fuel rods with internal pressure of $3 \ldots 5 \mathrm{MPa}$ and hydrogen concentration in $\mathrm{Zr}-1 \% \mathrm{Nb}$ claddings of $50 \ldots 300 \mathrm{ppm}$ were tested. The modes selected simulate SNF handling with maximum heating up to $410^{\circ} \mathrm{C}$ and accident conditions with seven $450 \leftrightarrow 300$ and $450 \leftrightarrow 180^{\circ} \mathrm{C}$ thermal cycles. Hydrogenation was done in the chamber without removing from the chamber before subsequent heating to $450^{\circ} \mathrm{C}$ and thermal cycling.

In the process of holding at $450^{\circ} \mathrm{C}$, pure hydrogen is fed through the hydrogen feed gate during one hour, after which the gate is closed and further heating occurs according to the preset mode. This test mode was selected as is it includes a sufficient number of corresponding process operations to complete the task set. In the process of the dummy testing, its geometry changes, furnace chamber environment changes and programmed temperature mode changes were continuously measured.

\section{CONCLUSION}

A facility for hydrogenation and thermal testing of internally pressurized dummy fuel rods was created allowing investigation of the processes occurring in fuel rods during the period of FA operation, SFA loading and storage in SFDSF.

It has been shown that the developed facility design, control and measurement devices, and dummy fuel rod design allow to conduct testing of the dummy fuel rods in the conditions, which are as close as possible (except for irradiation) to those of FR operation, loading and storage in SFDSF.

Статья поступила в редакиию 21.11.2019 2. 


\title{
УСТАНОВКА ДЛЯ ГИДРИРОВАНИЯ И ТЕРМИЧЕСКИХ ИСПЫТАНИЙ МАКЕТОВ ТВЭЛОВ ПОД ВНУТРЕННИМ ДАВЛЕНИЕМ
}

\author{
В.А. Долгий, В.А. Чуносов, Д.Л. Кокоша, Т.П. Черняева, В.М. Грицина, Г.П. Редкина
}

Представлена установка, которая позволяет проводить эксперименты с макетами твэлов длиной до 250 мм при температурах до $700{ }^{\circ} \mathrm{C}$. Уникальность спроектированной установки в том, что испытания, которые будут проводиться на ней, максимально приближены (исключая облучения) к тем испытаниям, что происходят в твэлах в период эксплуатации, загрузки и хранения в СХОЯТ. Все параметры испытания запрограммированы и регулируются специальными датчиками, что максимально приближает эксперимент по температурным воздействиям и давлению под оболочкой макетов твэлов к условиям работы твэлов в реакторе и последующего хранения в СХОЯТ. Проведены испытания на переориентацию гидридов на макетах твэлов с внутренним давлением $3 \ldots 5$ МПа (при комнатной температуре) и концентрацией водорода 50...300 ppm в режимах, имитирующих перегрузки ОЯТ с предельным нагреванием до $410^{\circ} \mathrm{C}$ и аварийные ситуации с семикратным термоциклованием $410 \leftrightarrow 300$ и $410 \leftrightarrow 180{ }^{\circ} \mathrm{C}$. Показано, что эффективность влияния условий испытаний по указанным режимам переориентации гидридов повышается с увеличением концентрации водорода и повышением тангенциальных напряжений в оболочках макетов твэлов. Показано, что конструкция испытываемых образцов, устройства и измерения, параметры которых оцениваются в процессе испытаний и последующих исследований, полностью соответствуют всем требованиям для проведения данных испытаний.

\section{УСТАНОВКА ДЛЯ ГІДРУВАННЯ ТА ТЕРМІЧНИХ ВИПРОБУВАНЬ МАКЕТІВ ТВЕЛІВ ПІД ВНУТРІШНІМ ТИСКОМ}

\section{В.А. Долгій, В.О. Чуносов, Д.Л. Кокоша, Т.П. Черняєва, В.М. Грицина, Г.П. Рєдкіна}

Представлена установка, яка дозволяє проводити експерименти 3 макетами твелів довжиною до 250 мм при температурах до $700{ }^{\circ} \mathrm{C}$. Унікальність спроектованої установки в тому, що випробування, які будуть проводитися на ній, максимально приближені (за виключенням опромінення) до тих, що відбуваються в твелах у період експлуатації, завантаження і зберігання в ССВЯП. Всі параметри випробування запрограмовані і регулюються спеціальними датчиками, що максимально наближає експеримент за температурними впливами і тиском під оболонкою макетів твелів до умов роботи твелів у реакторі i подальшого зберігання в ССВЯП. Проведено випробування на переорієнтацію гідридів на макетах твелів 3 внутрішнім тиском $3 \ldots 5$ МПа (при кімнатній температурі) і з концентрацією водню $50 \ldots 300$ ррт у режимах, що імітують перевантаження ВЯП з граничним нагріванням до $410{ }^{\circ} \mathrm{C}$ i аварійні ситуації з семиразовим термоциклуванням $410 \leftrightarrow 300$ і $410 \leftrightarrow 180^{\circ} \mathrm{C}$. Показано, що ефективність впливу умов випробувань за вказаними режимами на переорієнтацію гідридів підвищується зі збільшенням концентрації водню i підвищенням тангенціальних напружень в оболонках макетів твелів. Показано, що конструкція випробовуваних зразків, пристрої контролю та вимірювань, параметри яких оцінюються в процесі випробувань і наступних досліджень, повністю відповідають усім вимогам для проведення даних випробувань. 